\title{
Pharmacokinetics and residue depletion of praziquantel in rice field eels Monopterus albus
}

\author{
Ning $\mathrm{Xu}^{1,2,3}$, Jing Dong ${ }^{1,2,3}$, Yibin Yang ${ }^{1}$, Xiaohui $\mathrm{Ai}^{1,3, *}$ \\ ${ }^{1}$ Freshwater Fish Germplasm Quality Supervision and Testing Center, Ministry of Agriculture, \\ Yangtze River Fisheries Research Institute, Chinese Academy of Fishery Sciences, Wuhan 430223, PR China \\ ${ }^{2}$ Freshwater Fisheries Research Center, Chinese Academy of Fishery Sciences, Wuxi, 214081, PR China \\ ${ }^{3} \mathrm{Hu}$ Bei Freshwater Aquaculture Collaborative Innovation Center, Wuhan 430070, PR China
}

\begin{abstract}
We investigated the pharmacokinetic characteristics of praziquantel (PZQ) in rice field eels Monopterus albus. Pharmacokinetic parameters were determined following a single intravenous administration (5 $\mathrm{mg} \mathrm{kg}^{-1}$ body weight [bw]) and a single oral administration (10 mg $\left.\mathrm{kg}^{-1} \mathrm{bw}\right)$ at $22.0 \pm 0.7^{\circ} \mathrm{C}$. We also evaluated residue depletion in tissues following daily administration of PZQ $\left(10 \mathrm{mg} \mathrm{kg}^{-1} \mathrm{bw}\right)$ that was given orally for 3 consecutive days at $22.0 \pm 0.7^{\circ} \mathrm{C}$. Following intravenous treatment, the plasma concentration-time curve was best described by a 3compartment open model, with distribution half-life $\left(t_{1 / 2 \alpha}\right)$, elimination half-life $\left(t_{1 / 2 \beta}\right)$, and area under the concentration-time curve (AUC) of $0.54 \mathrm{~h}, 17.10 \mathrm{~h}$, and $14505.12 \mathrm{~h} \mathrm{\mu g} \mathrm{l}^{-1}$, respectively. After oral administration, the plasma concentration-time curve was best described by a 1-compartment open model with first-order absorption, with absorption half-life $\left(t_{1 / 2 \mathrm{Ka}}\right)$, elimination halflife $\left(t_{1 / 2 K \mathrm{~K}}\right)$, peak concentration $\left(C_{\max }\right)$, time-to-peak concentration $\left(T_{\max }\right)$, and AUC estimated to be $2.28 \mathrm{~h}, 6.66 \mathrm{~h}, 361.29 \mathrm{~g} \mathrm{l}^{-1}, 5.36 \mathrm{~h}$, and $6065.46 \mathrm{~h} \mu \mathrm{g} \mathrm{l}^{-1}$, respectively. The oral bioavailability $(F)$ was $20.9 \%$. With respect to residue depletion of $\mathrm{PZQ}$, the $t_{1 / 2 \beta}$ values of muscle, skin, liver, and kidney were 20.2, 28.4, 14.9, and $54.1 \mathrm{~h}$, respectively. Our results indicated rapid absorption, rapid elimination, and low bioavailability of PZQ in rice field eels at the tested dosing conditions.
\end{abstract}

KEY WORDS: Pharmacokinetics $\cdot$ Residue depletion $\cdot$ Praziquantel $\cdot$ Monopterus albus

\section{INTRODUCTION}

The rice field eel Monopterus albus, commonly known as 'ginseng in water,' is a freshwater fish species distributed in China, Japan, and Southeast Asia. As its flesh contains large amounts of protein, vitamins, and minerals, this species is valued as a food resource in addition to having medicinal values. The rice field eel has become one of the most popular fish species in China and is widely and intensively cultured in many provinces. For example, it is estimated that in excess of 30 million $\mathrm{m}^{2}$ are used for rice field eel cultured in Hubei Province, yielding an annual production of $65000 \mathrm{t}$ (valued at 2.0 billion $\mathrm{RMB}=$ US\$ 308.2 million) in 2004 (Chen 2010).
With the development and expansion of rice field eel culture, a large number of disease issues have been identified. These diseases have impeded the development of the rice field eel aquaculture industry with serious economic consequences. Of these, parasitic diseases are very important, as they often cause reductions in feed conversion and growth, as well as direct and indirect mortalities of rice field eels. Previous studies have identified 18 species of parasite in rice field eels from China, which include Neosentis celatus, Pallisentis celatus, Trypanosoma monopter, Cryptobia agitata, Agamospirura sp., Eustrongylides sp., Philometrosis sp., Paraseuratoides acuminicauda, Polyuoncobothrium magnum, Polyoncobothrium sp., Azygia anguilae, 
Diplostomulum hupehensis, D. nieckashui, Phyllodistomum serrispatula, Cephalogonimidae gen. et sp., Deretrema plaglorchis, Prosorchis tianjinensis, and Proterometra guangzhouensis (Wen 2003, Huang et al. 2014). Of these, infections with Neosentis celatus, Pallisentis celatus, and Eustrongylides sp. are more common than others (Huang et al. 2014).

In order to reduce the economic losses caused by parasites in rice field eels, it is important that an appropriate drug for therapy is chosen. Praziquantel (PZQ: 2-cyclohexylcarbonyl-1, 2, 3, 6, 7, 11b-hexahydro-4H-pyrazino [2,1-a] iso-quinoline-4-one) is a broad-spectrum anthelmintic drug used in human and veterinary medicine. In aquaculture, PZQ is mainly used for controlling and killing acanthocephalans (Paterson et al. 2013), trematodes (Kim \& Cho 2000, Montero et al. 2004, Mansell et al. 2005, Reimschuessel et al. 2011), cestodes (Pool 1985, Kline et al. 2009, lles et al. 2012), and other parasites of fish. Although PZQ is applied widely in the treatment of aquatic animals, only a few studies have examined the pharmacokinetics and tissue residues of PZQ in fish (K. Kim et al. 2001, C. Kim et al. 2003, Tubbs \& Tingle 2006a,b, Osman et al. 2008, Xie et al. 2015). Furthermore, no information is available on the pharmacokinetic profile and residue depletion of PZQ in rice field eels. Therefore, the goal of this study was to investigate aspects of the pharmacokinetics of $\mathrm{PZQ}$ in rice field eels, including bioavailability and tissue residues.

\section{METHODS AND RESULTS}

\section{Chemicals and reagents}

We used analytical standard PZQ (purity grade 99.5\%) and internal standard PZQ- $\mathrm{d}_{11}$ (purity grade 98.0; Dr. Ehrenstorfer). PZQ powder (purity grade $98.0 \%$ ) was used for oral and intravenous administration (Zhongbo Aquaculture Biotechnology). The anesthetic tricaine methanesulfonate (MS222) was purchased from Aibo Biotechnology. The purity of other chemicals and reagents was analytical grade.

Stock standard solutions of PZQ $\left(100 \mu \mathrm{g} \mathrm{ml}^{-1}\right)$ and PZQ- $\mathrm{d}_{11}\left(100 \mu \mathrm{g} \mathrm{ml}^{-1}\right)$ were prepared by dissolving these chemicals in dimethyl sulfoxide. Stock standards were stored at $-18^{\circ} \mathrm{C}$ and were stable for $6 \mathrm{mo}$. Intermediate solvent standard solutions $\left(1 \mathrm{\mu g} \mathrm{ml}^{-1}\right)$ were prepared by diluting PZQ or PZQ- $\mathrm{d}_{11}$ stock solutions with acetonitrile. These solutions were stored at $4^{\circ} \mathrm{C}$.
The PZQ solution for intravenous administration was prepared by dissolving PZQ powder in a minute quantity of dimethyl sulfoxide ( $\leq 1 \%$ of total volume) and adjusting with physiological saline to the final concentration of $5 \mathrm{mg} \mathrm{ml}^{-1}$.

The PZQ solution for oral administration was prepared by dissolving PZQ powder in a minute quantity of dimethyl sulfoxide ( $\leq 1 \%$ of total volume) and adjusting with physiological saline to the final concentration of $10 \mathrm{mg} \mathrm{ml}^{-1}$.

\section{Animal care and husbandry}

A total of 200 rice field eels $(150 \pm 15 \mathrm{~g})$ were obtained from the culturing base of the Yangtze River Fisheries Research Institute. The eels were held in plastic tanks $(100 \times 60 \times 80 \mathrm{~cm}$, length $\times$ width $x$ depth) that were supplied with flowing well water $\left(26 \mathrm{l} \mathrm{min}^{-1}\right)$. Water quality parameters were measured daily in each tank, and water quality was maintained as follows: total ammonia nitrogen levels $\leq 0.75 \mathrm{mg} \mathrm{l}^{-1}$; nitrite nitrogen levels $<0.06 \mathrm{mg} \mathrm{l}^{-1}$; dissolved oxygen levels at 6.5-7.9 $\mathrm{mg} \mathrm{l}^{-1}$; temperature at $22.0 \pm 0.7^{\circ} \mathrm{C}$; and $\mathrm{pH} 7.3 \pm 0.2$. Eels were fed a drug-free feed and were acclimatized for $14 \mathrm{~d}$ prior to commencing the experiment. The fish were divided into 3 groups, viz. the pharmacokinetic study group ( $\mathrm{n}=138)$, the residue study group $(\mathrm{n}=30)$, and controls $(\mathrm{n}=6)$. Prior to drug administration, the eels fasted for $24 \mathrm{~h}$. The control samples were collected from 6 eels on the last sampling date. All experimental procedures involving animals in the study were approved by the Animal Care Center, Hubei Academy of Medical Sciences.

\section{Pharmacokinetic study and sampling}

Eels in the pharmacokinetic study group were further divided into 2 groups, i.e. one group that received a single intravenous treatment and another that received a single oral treatment. The dose used for oral administration was that specified for treatment of fish by the National Standards for Veterinary Medicine in China. As the solubility of PZQ is only $0.04 \mathrm{~g}$ in water $(100 \mathrm{~g})$, we used a low concentration $(\leq 1 \%$ of total volume) of dimethyl sulfoxide to increase its solubility in physiological saline. The PZQ concentration for intravenous administration was determined to be $5 \mathrm{mg} \mathrm{ml}^{-1}$.

Eels in the intravenous treatment group were anesthetized with MS $222\left(50 \mathrm{mg} \mathrm{l}^{-1}\right)$ and injected at a 
dose of $5 \mathrm{mg} \mathrm{kg}^{-1}$ body weight (bw) with a $1 \mathrm{ml}$ micro-injector. The position of the needle in the caudal vein was confirmed by aspirating a small volume of blood into the syringe prior to injection. Fish that experienced heavy bleeding after withdrawal of the needle or in which the needle had translocated during injection were removed from the study and replaced. Samples of 6 eels were collected at 5, 10, and $30 \mathrm{~min}$, and 1, 2, 4, 8, 16, 24, 36, 48, and $72 \mathrm{~h}$ after intravenous treatment. At sampling, eels were anesthetized with MS $222\left(50 \mathrm{mg} \mathrm{l}^{-1}\right)$, and approximately $1.5 \mathrm{ml}$ of blood from each eel was drawn from the caudal vein away from the injection site. Blood samples were treated with heparin sodium solution (1\% heparin sodium in water) and centrifuged at $1500 \times g$ (10 min). The plasma was collected and stored at $-20^{\circ} \mathrm{C}$ until assayed. Following sampling, the fish were euthanized by an overdose in a solution of $300 \mathrm{mg} \mathrm{l}^{-1}$ MS 222.

Eels in the oral treatment group were anesthetized with MS $222\left(50 \mathrm{mg} \mathrm{l}^{-1}\right)$ prior to receiving an oral dose of $10 \mathrm{mg} \mathrm{kg}^{-1}$ bw PZQ. The oral dose was administered by inserting a plastic hose attached to a $1 \mathrm{ml}$ micro-injector into the stomach. After treatment, each fish was observed in a separate tank for regurgitation of PZQ. If PZQ solution was regurgitated, the fish was removed from the study and replaced. Subsequently, 6 fish were taken from the tank at each sampling point $(5,10$, and $30 \mathrm{~min}$, and $1,2,4,8,16$, 24,48 , and $72 \mathrm{~h}$ ) after the oral dose. At sampling, fish were anesthetized with MS $222\left(50 \mathrm{mg} \mathrm{l}^{-1}\right)$ and blood samples of approximately $1.5 \mathrm{ml}$ were collected and treated with $1 \%$ heparin sodium. Processing of the blood samples and storage of the plasma was conducted as described above. Following sampling, the fish were euthanized by an overdose in a solution of $300 \mathrm{mg} \mathrm{l}^{-1}$ MS 222.

\section{Residue depletion and sampling}

To examine PZQ tissue residues, eels were anesthetized with MS $222\left(50 \mathrm{mg} \mathrm{kg}^{-1}\right)$ prior to receiving an oral dose of $10 \mathrm{mg} \mathrm{kg}^{-1}$ bw PZQ, which was administered daily for $3 \mathrm{~d}$. The oral dose was administered as described above. At 16, 24, 48, 72, and $96 \mathrm{~h}$ after the final dose, 6 eels were anesthetized with MS $222\left(50 \mathrm{mg} \mathrm{l}^{-1}\right)$, and then blood and tissue samples were taken. Approximately $1.5 \mathrm{ml}$ of blood was drawn from each fish, treated with $1 \%$ heparin sodium solution, and centrifuged at $1500 \times g$ (10 min). The resulting plasma was collected and stored at $-20^{\circ} \mathrm{C}$ until assayed. Tissues (liver, kidney, muscle, and skin) were collected from standardized locations and transferred to $50 \mathrm{ml}$ polypropylene tubes. These samples were stored frozen at $-20^{\circ} \mathrm{C}$ until assayed.

\section{Analytical method}

Levels of PZQ in plasma and tissues were determined by liquid chromatography triple quadrupole mass spectrometry (LC-MS-MS; Thermo Scientific). The LC-MS-MS system consisted of a Surveyor Llus HPLC and TSQ Quantum Access Max. Data were obtained and processed using the Thermo Xcalibur software (Copyright 2.1.0). The chromatographic separation was performed on a Thermo Hypersil BDS octadecylsilane column $(100 \mathrm{~mm} \times$ $2.1 \mathrm{~mm}, 3 \mu \mathrm{m})$. The mobile phase was water containing $0.1 \%$ formic acid and acetonitrile (70:30, $\mathrm{v} / \mathrm{v})$. The total run time of a sample was $8.0 \mathrm{~min}$. The injection volume was $10 \mu \mathrm{l}$, and the column temperature was $30^{\circ} \mathrm{C}$.

The instrument was operated using heated electrospray ionization in positive ion mode. The ion source parameters were optimized by monitoring the PZQ mass spectra. Selective reaction monitoring was performed on PZQ protonated molecular ions using a spray voltage of $3500 \mathrm{~V}$, vaporizer temperature of $300^{\circ} \mathrm{C}$, ion transport tube temperature of $350^{\circ} \mathrm{C}$, sheath gas (high purity nitrogen) of $40 \mathrm{arb}$, auxiliary gas (high purity nitrogen) of 10, collision gas (ultrahigh purity argon) pressure of 1.50 mTorr, scan width of 0.010 , and a scan time of $0.200 \mathrm{~s}$. Selective reaction monitoring for PZQ was $\mathrm{m} / \mathrm{z} 313.3$ to 174.1 (qualitative) with a collision energy of $28 \mathrm{eV}$, and $\mathrm{m} / \mathrm{z} 313.3$ to 203.1 (quantitative) with a collision energy of $16 \mathrm{eV}$. Selective reaction monitoring for PZQ- $\mathrm{d}_{11}$ was $\mathrm{m} / \mathrm{z} 324.1$ to 204.1 (quantitative) with collision energy of $17 \mathrm{eV}$.

Plasma and tissue samples were prepared using a modification of the methods given by $\mathrm{Kim}$ et al. (2001). Briefly, plasma samples were thawed at $25^{\circ} \mathrm{C}$ and vortexed for $2 \mathrm{~min}$, and $1 \mathrm{ml}$ subsamples were transferred into $10 \mathrm{ml}$ polypropylene tubes. To each tube, $20 \mu \mathrm{l}$ of internal standard $\left(1 \mu \mathrm{g} \mathrm{m} \mathrm{l}^{-1}\right)$ were added and the resulting plasma/internal solutions were vortexed for $1 \mathrm{~min}$. Acetonitrile $(1 \mathrm{ml})$ was added into the $10 \mathrm{ml}$ polypropylene tubes, mixed, and incubated for $10 \mathrm{~min}$ at $4^{\circ} \mathrm{C}$, after which the tubes were vortexed and centrifuged at $5500 \times \mathrm{g}$ (5 min). The resulting supernatants were filtered through $0.22 \mu \mathrm{m}$ nylon filters prior to LC-MS-MS analysis. 
Tissues were thawed at $25^{\circ} \mathrm{C}$, and $2 \mathrm{~g}$ portions of the various tissues were weighed into $50 \mathrm{ml}$ polypropylene tubes. To each tube, $10 \mu \mathrm{l}$ of internal standard $\left(1 \mu \mathrm{g} \mathrm{ml} \mathrm{m}^{-1}\right)$ were added and the tissue was homogenized using a homogenizer (PRO Scientific). After homogenization, $5 \mathrm{ml}$ of acetonitrile were added into the tube, and the samples were mixed and incubated for $10 \mathrm{~min}$ at $4^{\circ} \mathrm{C}$, after which they were vortexed and centrifuged at $5500 \times g(5 \mathrm{~min})$. The resulting supernatants were then transferred to new tubes. The tissues were extracted a second time as described above, and the supernatants from the 2 extractions were pooled. Supernatants were evaporated to dryness with a gentle stream of nitrogen at $40^{\circ} \mathrm{C}$, and the residue was reconstituted in $1 \mathrm{ml}$ of acetonitrile and water (30:70). The resulting solutions were centrifuged at $5500 \times g(5 \mathrm{~min})$ and filtered through $0.22 \mu \mathrm{m}$ nylon filters prior to LC-MS-MS analysis.

\section{Calibration curves and recovery rates}

Plasma and tissue samples were obtained from untreated fish following the methods described above. Plasma from untreated eels was spiked with a standard solution of PZQ and the internal standard to yield concentrations of 5,50,500,3000, and $6000 \mu \mathrm{g}$ $\mathrm{l}^{-1}$ and $10 \mu \mathrm{g} \mathrm{l}^{-1}$ internal standard (Table 1 ). Tissues (muscle, liver, kidney, and skin) from untreated fish were also spiked with a standard solution of PZQ and internal standard to yield concentrations of 5, 50,500, 1000, and $2000 \mu \mathrm{g} \mathrm{kg}^{-1}$ and $10 \mu \mathrm{g} \mathrm{kg}^{-1}$ internal standard. Samples were prepared as described above, and each concentration was assayed in triplicate. Precision and accuracy were determined by analyzing 5 replicates of spiked plasma and tissue samples at 5, 50, and $500 \mu \mathrm{g} \mathrm{PZQ} \mathrm{l}^{-1}$ (Table 2).

\section{Pharmacokinetic and statistical analyses}

Pharmacokinetic parameters (Table 3) were calculated using the Practical Pharmacokinetic Program 3P97 (Mathpharmacology Committee, Chinese Academy of Pharmacology, Beijing, China). The appropriate pharmacokinetic model was selected by the visual examination of the concentration-time curve and by application of Akaike's information criterion (Yamaoka et al. 1978). The elimination half-life for 2and 3-compartment models $\left(t_{1 / 2 \beta}\right)$ was calculated as $t_{1 / 2 \beta}=0.693 / \beta$. The oral bioavailability $(F)$ for $\mathrm{PZQ}$
Table 1. Calibration equation and correlation coefficient of praziquantel matrix-fortified in plasma and tissues of rice field eels Monopterus albus

\begin{tabular}{|lccc|}
\hline Tissue & $\begin{array}{c}\text { Linear range } \\
\left(\mu \mathrm{g}^{-1} \text { or } \mu \mathrm{kg}^{-1}\right)\end{array}$ & $\begin{array}{c}\text { Calibration } \\
\text { equation }\end{array}$ & $\begin{array}{c}\text { Correlation } \\
\text { coefficient }\left(\mathrm{R}^{2}\right)\end{array}$ \\
\hline Plasma & $5.0-6000.0$ & $y=0.0599 x-0.2394$ & 0.9994 \\
Muscle & $5.0-6000.0$ & $y=0.0753 x-0.0982$ & 1 \\
Liver & $5.0-6000.0$ & $y=0.0812 x-0.1332$ & 0.9997 \\
Kidney & $5.0-6000.0$ & $y=0.0702 x+0.4578$ & 0.9991 \\
Skin & $5.0-6000.0$ & $y=0.0752 x+0.2376$ & 0.9993 \\
\hline
\end{tabular}

Table 2. Recovery efficiency of praziquantel (PZQ) in samples of rice field eel Monopterus albus plasma and tissues that were spiked with different concentrations of PZQ $(n=3)$

\begin{tabular}{|cccc|}
\hline \multirow{2}{*}{ Tissue } & $\begin{array}{c}\text { PZQ amount added } \\
\left(\mu \mathrm{l}^{-1} \text { or } \mu \mathrm{kg}^{-1}\right)\end{array}$ & $\begin{array}{c}\text { Recovery } \\
(\%)\end{array}$ & $\begin{array}{c}\text { Relative standard } \\
\text { deviation }(\%)\end{array}$ \\
\hline Plasma & 5 & 95.28 & 1.23 \\
& 50 & 99.80 & 2.62 \\
Muscle & 500 & 99.71 & 2.43 \\
& 5 & 93.70 & 2.92 \\
Liver & 50 & 96.71 & 2.87 \\
& 500 & 99.93 & 3.32 \\
& 5 & 95.61 & 4.55 \\
Kidney & 50 & 98.21 & 3.57 \\
& 500 & 103.89 & 3.89 \\
\multirow{4}{*}{ Skin } & 50 & 92.74 & 1.58 \\
& 500 & 98.15 & 3.01 \\
& 5 & 96.45 & 2.77 \\
& 50 & 94.52 & 3.52 \\
& 500 & 100.92 & 2.89 \\
& & 97.28 & 2.57 \\
\hline
\end{tabular}

was determined by calculating the area under the concentration-time curve (AUC) after oral and intravenous administration and using the equation $F=t$ order absorption. The absorption rate constant $\left(K_{\mathrm{a}}\right)$, elimination rate constant $\left(K_{\mathrm{e}}\right)$, absorption half-life $\left(t_{1 / 2 K a}\right)$, and elimination half-life for 1-compartment models $\left(t_{1 / 2 \mathrm{Ke}}\right)$ were $0.30,0.10,2.28$ and $6.66 \mathrm{~h}^{-1}$, respectively. The corresponding values of the apparent distribution volume $(V / F)$, AUC, peak concentration $\left(C_{\max }\right)$, and time-to-peak concentration

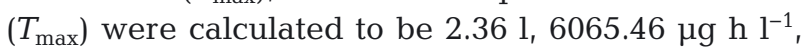
$361.29 \mathrm{\mu g} \mathrm{l}^{-1}$, and $5.36 \mathrm{~h}$ (Fig. 3, Table 3). The oral bioavailability was $20.91 \%$.

The mean concentrations of PZQ following multiple-dose treatment are given in Table 4 . The concentrations of $\mathrm{PZQ}$ in muscle were significantly lower than that in other tissues, and levels of PZQ were below the level of detection at $72 \mathrm{~h}$ after the final dose. Although the concentration of PZQ in liver was 
Table 3. Pharmacokinetic parameters for praziquantel in rice field eel Monopterus albus following a single intravenous administration (5 $\mathrm{mg} \mathrm{kg}^{-1}$ body weight, bw) or a single oral administration (10 $\mathrm{mg} \mathrm{kg}^{-1} \mathrm{bw}$ ) (n $=6$ for each treatment). $P$, $A, B$ : zero-time blood drug concentration intercept of triphasic disposition curve; $\pi, \alpha$ : distribution rate constants; $\beta$ : elimination rate constant; $K_{\mathrm{a}}$ : absorption rate constants; $K_{\mathrm{e}}$ : elimination rate constants; $t_{1 / 2 \pi}, t_{1 / 2 \alpha}$ : distribution half-lives; $t_{1 / 2 \beta}$ : elimination half-life for 2- and 3-compartment models; $t_{1 / 2 K a}:$ absorption half-life; $t_{1 / 2 K \mathrm{~K}}$ : elimination half-life for 1 compartment models; $K_{10}$ : drug elimination rate constant from central compartment; $K_{12}, K_{21}$ : first-order transport rate constant between the central compartment and the shallow peripheral compartment; $K_{13}, K_{31}$ : first-order transport rate constant between the central compartment and the deep peripheral compartment; AUC: area under the concentration-time curve; $T_{\max }$ : time to peak concentration; $C_{\max }$ : peak concentration; VIF: extensive apparent volume of the central compartment; $\mathrm{CL}_{\mathrm{b}}$ : total body clearance of the drug

\begin{tabular}{|c|c|c|c|}
\hline \multicolumn{2}{|c|}{ Intravenous administration } & \multicolumn{2}{|c|}{ Oral administration } \\
\hline Parameter & Value & Parameter & Value \\
\hline$P\left(\mu g \mathrm{l}^{-1}\right)$ & 20227.29 & & \\
\hline$\pi\left(\mathrm{h}^{-1}\right)$ & 19.56 & & \\
\hline$A\left(\mu g l^{-1}\right)$ & 1499.86 & & \\
\hline$\alpha\left(\mathrm{h}^{-1}\right)$ & 1.27 & & \\
\hline$B\left(\mu g \mathrm{l}^{-1}\right)$ & 498.21 & $K_{\mathrm{a}}\left(\mathrm{h}^{-1}\right)$ & 0.30 \\
\hline$\beta\left(\mathrm{h}^{-1}\right)$ & 0.041 & $K_{\mathrm{e}}\left(\mathrm{h}^{-1}\right)$ & 0.10 \\
\hline$t_{1 / 2 \pi}(\mathrm{h})$ & 0.035 & & \\
\hline$t_{1 / 2 \alpha}(\mathrm{h})$ & 0.54 & $t_{1 / 2 K a}(\mathrm{~h})$ & 2.28 \\
\hline$t_{1 / 2 \beta}(\mathrm{h})$ & 17.10 & $t_{1 / 2 \mathrm{Ke}}(\mathrm{h})$ & 6.66 \\
\hline$K_{12}\left(\mathrm{~h}^{-1}\right)$ & 9.74 & & \\
\hline$K_{21}\left(\mathrm{~h}^{-1}\right)$ & 2.74 & & \\
\hline$K_{13}\left(\mathrm{~h}^{-1}\right)$ & 6.62 & $V / F(\mathrm{l})$ & 2.36 \\
\hline$K_{31}\left(\mathrm{~h}^{-1}\right)$ & 0.24 & $T_{\text {peak }}(\mathrm{h})$ & 5.36 \\
\hline$K_{10}\left(\mathrm{~h}^{-1}\right)$ & 1.53 & $C_{\max }\left(\mu \mathrm{g} \mathrm{l}^{-1}\right)$ & 361.29 \\
\hline AUC $\left(\mu g \mathrm{~h} \mathrm{l}^{-1}\right)$ & 14505.12 & $\operatorname{AUC}\left(\mu g \mathrm{~h} \mathrm{l}^{-1}\right)$ & 6065.46 \\
\hline $\mathrm{CL}_{\mathrm{b}}\left(\mathrm{l} \mathrm{h}^{-1}\right)$ & 0.052 & $\mathrm{CL}_{\mathrm{b}}\left(\mathrm{l} \mathrm{h}^{-1}\right)$ & 0.25 \\
\hline
\end{tabular}

significantly higher than that in muscle, kidney, and skin from 16 to $48 \mathrm{~h}$ post-treatment, it was also undetectable at $72 \mathrm{~h}$. The residual time of PZQ in skin and kidney was longer than that of liver and muscle, and

Table 4. Praziquantel (PZQ) concentrations (mean \pm SD) in plasma and tissues of rice field eels Monopterus albus after oral administration at a dose of $10 \mathrm{mg} \mathrm{kg}^{-1}$ body weight (bw) for 3 consecutive days ( $\mathrm{n}=6$ samples per time point). ND: not detected

\begin{tabular}{|c|c|c|c|c|c|}
\hline \multirow{2}{*}{$\begin{array}{l}\text { Time } \\
\text { (h) }\end{array}$} & \multicolumn{5}{|c|}{ PZQ concentration ( $\mu g \mathrm{l}^{-1}$ or $\mu \mathrm{g} \mathrm{kg}^{-1}$ ) } \\
\hline & Plasma & Liver & Kidney & Muscle & Skin \\
\hline 16 & $623.8 \pm 23.9$ & $430.7 \pm 30.8$ & $33.1 \pm 4.5$ & $29.3 \pm 3.1$ & $198.1 \pm 20.7$ \\
\hline 24 & $173.5 \pm 18.7$ & $354.7 \pm 12.5$ & $32.2 \pm 3.9$ & $24.2 \pm 4.0$ & $68.9 \pm 11.3$ \\
\hline 48 & $53.2 \pm 5.5$ & $102.4 \pm 8.9$ & $19.9 \pm 2.4$ & $10.0 \pm 2.1$ & $43.7 \pm 5.5$ \\
\hline 72 & ND & ND & $17.4 \pm 1.3$ & ND & $21.4 \pm 3.2$ \\
\hline 96 & ND & ND & ND & ND & ND \\
\hline
\end{tabular}

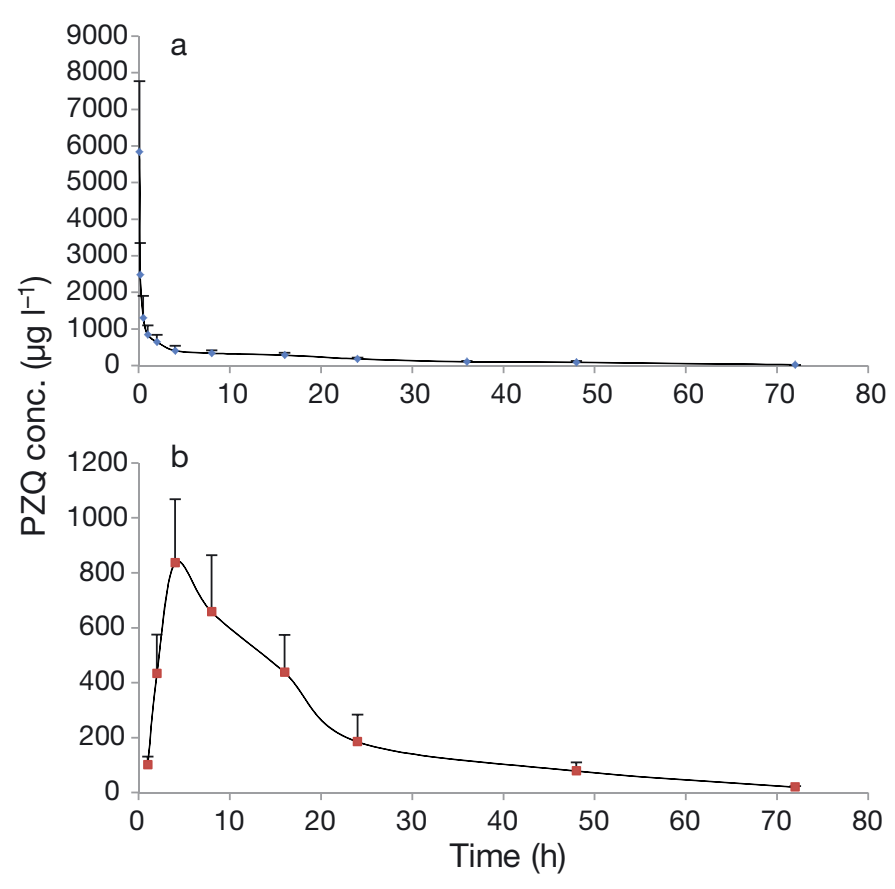

Fig. 1. Mean $( \pm \mathrm{SD})$ plasma concentration vs. time profiles of praziquantel (PZQ) in rice field eels Monopterus albus following (a) a single intravenous administration $\left(5 \mathrm{mg} \mathrm{kg}^{-1}\right.$ body weight, bw) and (b) a single oral administration (10 mg $\left.\mathrm{kg}^{-1} \mathrm{bw}\right)(\mathrm{n}=6$ samples per time point)

residues were still detected at $72 \mathrm{~h}$ after final dose in both of these tissues. The concentration of PZQ was highest in plasma at $16 \mathrm{~h}$, declining rapidly so that it was below the level of detection by $72 \mathrm{~h}$ after the final dose.

\section{DISCUSSION}

This study was designed to examine pharmacokinetic characteristics and depletion regularity of PZQ in the rice field eel. A 3-compartment model best described the pharmacokinetics of PZQ in eels after intravenous treatment, whereas a 1-compartment model with first-order absorption best fit the data from the oral treatment. Only a few studies have examined the pharmacokinetics of PZQ after a single dose in fish. The plasma concentration-time curves of grass carp Ctenopharyngodon idellus were best described by a 2-compartmental model after a single oral administration at dose of $10 \mathrm{mg} \mathrm{kg}^{-1}$ bw in freshwater and brackish water at $22 \pm 1^{\circ} \mathrm{C}$ (Xie et al. 2015). For kingfish Seriola 
lalandi following intravenous and oral administration at dose of $40 \mathrm{mg} \mathrm{kg}^{-1} \mathrm{bw}$ at $18-19^{\circ} \mathrm{C}$, a non-compartment model best described the data (Tubbs \& Tingle 2006a). These differences might result from fish species, sizes, temperatures, salinity of the environment, and experimental protocols (Rigos et al. 2002).

In our study, the time to peak concentration $\left(T_{\max }\right)$ and the peak concentration $\left(C_{\max }\right)$ following oral administration were estimated to be $5.36 \mathrm{~h}$ and $361.29 \mu \mathrm{g} \mathrm{l}^{-1}$, respectively. Tubbs \& Tingle (2006a) reported a peak concentration of $12.73 \mu \mathrm{g} \mathrm{ml}^{-1}$ at $1 \mathrm{~h}$ after oral treatment at a dose of $40 \mathrm{mg} \mathrm{kg}^{-1} \mathrm{bw}$. The concentrations that Kim et al. (2003) reported are much higher than achieved in our study, and this difference might be due to their use of a much higher dose. The elimination half-life $\left(t_{1 / 2 \beta}\right)$ after intravenous and oral treatment in rice field eels were 17.10 and $6.66 \mathrm{~h}$, respectively. The $t_{1 / 2 \beta}$ value in kingfish after intravenous treatment was about half of that in rice field eels, and the $t_{1 / 2 \beta}$ value after oral treatment was also lower than that in rice field eels (Tubbs \& Tingle 2006a). Hansen \& Horsberg (2000) reported a much longer distribution half-life for the European eel Anguilla anguilla following intravenous and oral administrations of flumequine when compared to other fish species. These authors suggested that physiological and anatomical differences of eel gills may be responsible for this difference. The gills are regarded as an important sites of elimination of xenobiotics in fish (Hansen et al. 2001); however, the gills and the circulation system of eels are characterized by an extremely low gill surface area, low blood hematocrit, small ventricular masses, and relatively low cardiac output, which results in the gills being less perfused than in other fish (Byczkowska-Smyk 1958, Hansen \& Horsberg 2000). In mammals, $t_{1 / 2 \beta}$ values are significantly shorter than in fish. For example, $t_{1 / 2 \beta}$ values in pigs after intravenous treatment at a dose of $10 \mathrm{mg} \mathrm{kg}^{-1} \mathrm{bw}$ and oral treatment at a dose of $50 \mathrm{mg} \mathrm{kg}^{-1} \mathrm{bw}$ were 1.5 and $1.07 \mathrm{~h}$, respectively (Zeng et al. 1993). In cattle, $t_{1 / 2 \beta}$ values after intravenous treatment at a dose of $10 \mathrm{mg} \mathrm{kg}^{-1} \mathrm{bw}$ were also shorter than in fish, but after oral treatment at a dose of $30 \mathrm{mg} \mathrm{kg}^{-1} \mathrm{bw}$, the values were close to those obtained from fish (Cao et al. 2011). These differences between mammals and fish might be due to differences in metabolic capacity. Similar differences have been observed between fish and mammals for the depletion of melamine and cyanuric acid (Stine et al. 2012).

The oral bioavailability $(F)$ of PZQ in rice field eels was $20.9 \%$ in the present study. Oral bioavailability of PZQ has been estimated for only a few fish species.
A considerably higher $F$-value $(50.8 \%)$ was found in kingfish after oral administration $\left(40 \mathrm{mg} \mathrm{kg}^{-1} \mathrm{bw}\right)$ at $18-19^{\circ} \mathrm{C}$ (Tubbs \& Tingle 2006a). The large difference in $F$-values between our study and that of Tubbs \& Tingle (2006a) is likely due to their use of a much higher $(4 \times)$ dose of PZQ and other factors such as the route of drug administration and water temperature. The bioavailability of PZQ has been reported to be relatively low or low in other animals including cattle (32.3\%; Cao et al. 2011) and pigs (3.2\%; Zeng et al. 1993). Low bioavailability may be caused by rapid and extensive metabolism of PZQ in the liver of animals to mono- and dihydroxylated derivatives. This view is supported by a lack of PZQ detection in the excretion products of rats, dogs, and monkeys that received intravenous and oral doses of ${ }^{14} \mathrm{C}-\mathrm{PZQ}$ (EMEA 1996). In addition, the metabolism of $P Z Q$ was found to be rapid: $15 \mathrm{~min}$ after oral and intravenous dosing, the serum radioactivity consisted of 99 and $54 \%$ metabolites in rats, 84 and $59 \%$ in dogs, and 99 and $50 \%$ in monkeys, respectively (EMEA 1996).

Factors affecting metabolism of PZQ in fish require further investigation. PZQ is metabolized into hydroxylated derivatives in kingfish; however, the predominant metabolite was different from that found in mammals (Tubbs et al. 2008). Some studies of mammals have demonstrated that the site of hydroxylation is in the cyclohexyl ring (Lerch \& Blaschke 1998, Meier \& Blaschke 2001, Schepmann \& Blaschke 2001); however, whether this is the case in fish is unknown.

The residue depletion of PZQ was determined in various tissues of rice field eels. At $16 \mathrm{~h}$ post treatment, PZQ concentrations were much higher in liver when compared to the other tissues, although these concentrations rapidly declined to below the level of detection by $72 \mathrm{~h}$. In kidney and skin, levels were initially lower and PZQ was retained for longer periods of time. The $t_{1 / 2 \beta}$ values of PZQ in liver, kidney, muscle, and skin were $14.9,54.1,20.2$, and $28.4 \mathrm{~h}$, respectively. Higher concentrations and longer $t_{1 / 2 \beta}$ values were observed in muscle of rockfish Sebastes schlegeli after a single oral treatment of PZQ at dose of $400 \mathrm{mg} \mathrm{kg}^{-1}$ bw (K. Kim et al. 2001, C. Kim et al. 2003). A similar result was reported for rainbow trout Oncorhynchus mykiss following a single oral administration at a dose of $500 \mathrm{mg} \mathrm{kg}^{-1}$ bw (Björklund \& Bylund 1987). The differences between our results and those obtained for rockfish and rainbow trout are likely due to our use of a much lower concentration of $P Z Q$, as well as differences in water temperature and other conditions of culture. Regardless of the dose, 
rapid depletion of PZQ occurred in every study. In rainbow trout, $67-96 \%$ of the maximum amounts had been excreted by $32 \mathrm{~h}$ after oral administration (Björklund \& Bylund 1987). In mammals, PZQ is more rapidly eliminated (Zeng et al. 1993, Cao et al. 2011).

The present study demonstrated that PZQ is rapidly distributed and rapidly eliminated in rice field eels after oral and intravenous treatment. The residual time of PZQ was also short in rice field eel following daily administration over a period of $3 \mathrm{~d}$. These data along with the known efficacy of PZQ against a wide range of parasites suggests that this drug may be suitable for the treatment of parasitic diseases of the rice field eel.

Acknowledgements. This work was financially supported by the National Nonprofit Institute Research Grant of Freshwater Fisheries Research Center, CAFS (2015JBFM29) and the Special Fund for Agro-Scientific Research in the Public Interest of China (201203085).

\section{LITERATURE CITED}

Björklund H, Bylund G (1987) Absorption, distribution and excretion of the anthelmintic praziquantel (Droncit) in rainbow trout (Salmo gairdneri R.). Parasitol Res 73: 240-244

Byczkowska-Smyk W (1958) The respiratory surface of the gills in teleosts. Acta Biol Cracov Ser Zool 1:831-837

Cao JY, Liu EY, Zhao JL, Li KB, Dou SL (2011) Pharmacokinetics and bioavailability of praziquantel in cattle after oral, intramuscular and intravenous administration. Chin J Vet Sci 21:612-614

Chen XL (2010) Study on preventive measures for Aeromonas hydrophila and Aeromonas sobria in rice field eel (Monopterus albus). MSc thesis, Sichuan Agricultural University

EMEA (European Medicines Evaluation Agency) (1996) Praziquantel summary report by CVMP. EMEA/MRL/ 141/96-Final September 1996. EMEA, London

> Hansen MK, Horsberg TE (2000) Single-dose pharmacokinetics of flumequine in the eel (Anguilla anguilla) after intravascular, oral and bath administration. J Vet Pharmacol Ther 23:169-174

Hansen MK, Ingebrigtsen $\mathrm{K}$, Hayton WL, Horsberg TE (2001) Disposition of ${ }^{14} \mathrm{C}$-flumequine in eel Anguilla anguilla, turbot Scophthalmus maximus and halibut Hippoglossus hippoglossus after oral and intravenous administration. Dis Aquat Org 47:183-191

Huang JR, Chen XX, Huang BL, Chen S, Li D, Li L, Chen JP (2014) Parasites in rice field eels in mainland China and related human infectious [sic]. J Prev Med Inf 30: 777-782

Iles AC, Archdeacon TP, Bonar SA (2012) Novel praziquantel treatment regime for controlling Asian tapeworm infections in pond-reared fish. $\mathrm{N}$ Am J Aquacult 74: 113-117

Kim CS, Cho JB, Ahn KJ, Lee JI, Kim KH (2003) Depletion of praziquantel in muscle tissue and skin of cultured rockfish (Sebastes schlegeli) under the commercial culture conditions. Aquaculture 219:1-7

Kim KH, Cho JB (2000) Treatment of Microcotyle sebastis (Monogenea: Polyopisthocotylea) infestation with praziquantel in an experimental cage simulating commercial rockfish Sebastes schlegeli culture conditions. Dis Aquat Org 40:229-231

> Kim KH, Kim CS, Kim JW (2001) Depletion of praziquantel in plasma and muscle tissue of cultured rockfish Sebastes schlegeli after oral and bath treatment. Dis Aquat Org 45:203-207

Kline SJ, Archdeacon TP, Bonar SA (2009) Effects of praziquantel on eggs of the Asian tapeworm Bothriocephalus acheilognathi. N Am J Aquacult 71:380-383

Lerch C, Blaschke G (1998) Investigation of the stereoselective metabolism of praziquantel after incubation with rat liver microsomes by capillary electrophoresis and liquid chromatography-mass spectrometry. J Chromatogr B Biomed Sci Appl 708:267-275

> Mansell B, Powell MD, Ernst I, Nowak BF (2005) Effects of the gill monogenean Zeuxapta seriolae (Meserve, 1938) and treatment with hydrogen peroxide on pathophysiology of kingfish, Seriola lalandi Valenciennes, 1833. J Fish Dis 28:253-262

Meier H, Blaschke G (2001) Investigation of praziquantel metabolism in isolated rat hepatocytes. J Pharm Biomed Anal 26:409-415

> Montero FE, Crespo S, Padros F, De la Gandara F, Garcia A, Raga JA (2004) Effects of the gill parasite Zeuxapta seriolae (Monogenea: Heteraxinidae) on the amberjack Seriola dumerili Risso (Teleostei: Carangidae). Aquaculture 232:153-163

Osman HAM, Borhn T, El Deen AEN, El-Bana LF (2008) Estimation of skin and gill monogenea and musculature in $O$. niloticus treated by praziquantel using HPLC. Life Sci J 5:77-82

Paterson RA, Rauque CA, Valeria Fernandez M, Townsend CR, Poulin R, Tompkins DM (2013) Native fish avoid parasite spillback from multiple exotic hosts: consequences of host density and parasite competency. Biol Invasions 15:2205-2218

Pool DW (1985) The effect of praziquantel on the pseudophyllidean cestode Bothriocephalus acheilognathi in vitro. Z Parasitenkd 71:603-608

Reimschuessel R, Gieseker C, Poynton S (2011) In vitro effect of seven antiparasitics on Acolpenteron ureteroecetes (Dactylogyridae) from largemouth bass Micropterus salmoides (Centrarchidae). Dis Aquat Org 94: $59-72$

Rigos G, Tyrpenou A, Nengas I, Alexis M (2002) A pharmacokinetic study of flumequine in sea bass, Dicentrarchus labrax (L.), after a single intravascular injection. J Fish Dis 25:101-105

> Schepmann D, Blaschke G (2001) Isolation and identification of 8-hydroxypraziquantel as a metabolite of the antischistosomal drug praziquantel. J Pharm Biomed Anal 26:791-799

Stine CB, Nochetto CB, Evans ER, Gieseker CM, Mayer TD, Hasbrouck NR, Reimschuessel R (2012) Depletion of melamine and cyanuric acid in serum from catfish Ictalurus punctatus and rainbow trout Onchorhynchus [sic] mykiss. Food Chem Toxicol 50:3426-3432

Tubbs LA, Tingle MD (2006a) Bioavailability and pharmacokinetics of a praziquantel bolus in kingfish Seriola lalandi. Dis Aquat Org 69:233-238

Tubbs LA, Tingle MD (2006b) Effect of dose escalation on 
multiple dose pharmacokinetics of orally administered praziquantel in kingfish Seriola lalandi. Aquaculture 261:1168-1174

Tubbs L, Mathieson T, Tingle M (2008) Metabolism of praziquantel in kingfish Seriola lalandi. Dis Aquat Org 78: 225-233

Wen AX (2003) Study on parasites in ricefield eels. J Sichuan Agric Univ 21:43-46

Xie X, Zhao Y, Yang X, Hu K (2015) Comparison of praziquantel pharmacokinetics and tissue distribution in fresh

Editorial responsibility: Stewart Johnson, Nanaimo, British Columbia, Canada and brackish water cultured grass carp (Ctenopharyngodon idellus) after oral administration of single bolus. BMC Vet Res 11:84

Yamaoka K, Nakagawa T, Uno T (1978) Application of Akaike's information criterion (AIC) in the evaluation of linear pharmacokinetic equations. J Pharmacokinet Biopharm 6:165-175

Zeng ZL, Chen ZL, Feng QH (1993) Pharmacokinetics and oral bioavailability of praziquantel in pigs following a single dose. Chin J Anim Vet Sci 24:170-174

Submitted: April 20, 2015; Accepted: February 8, 2016

Proofs received from author(s): March 17, 2016 